\title{
SERODIAGNOSIS OF COWPEA (VIGNA UNGUICULATA) VIRUSES IN GUILAN PROVINCE, IRAN
}

\author{
Ghorbani S. G. M., ${ }^{12} *$ Shahraeen $\mathrm{N}^{1}$ and Elahinia S. A. ${ }^{2}$ \\ 1-Iranian Research Institute of Plant Protection, Dept. of Plant Virology, Tehran. \\ 2-University of Guilan, Dept. of Plant Protection, Rasht.
}

\begin{abstract}
Damage to cowpea crops by different viruses has occurred in Iran in the past. A total of 119 symptomatic samples were collected from cowpea fields throughout Guilan province, Iran during the summer 2006 and 10 viruses tested by Double Antibody Sandwich Enzyme Linked Immuno Sorbent Assay (DAS-ELISA), 7 viruses tested by Tissue Blot Immuno Assay (TBIA) and Antigen Coated-Plate (ACP-ELISA) used for detection of the Potyviruses. Using DAS-ELISA Bean leaf Roll Virus-BLRV (10\%), Cowpea Mild Mottle Virus-CpMMV (4\%), Cowpea Mottle Virus-CpMoV (6\%), Cowpea Mosaic Virus-CpMV (10\%), Southern Bean Mosaic Virus-SBMV (1\%), Cucumber Mosaic Virus-CMV (13\%), Cowpea Aphid Borne Mosaic Virus-CABMV (0.8\%), Bean Yellow Mosaic Virus-BYMV (3\%), Cowpea Chlorotic Mottle Virus-CCMV (2\%) was identified and application of TBIA test, the samples were shown infection to Cowpea Severe Mosaic Virus-CpSMV (13\%), Bean Common Mosaic Virus-BCMV (25\%), Alfalfa Mosaic Virus-AMV (12\%), Bean Pod Mottle Virus-BPMV (5\%), Clover Yellow Vein Virus-CYVV (2\%), Peanut Stunt Virus-PSV (6\%) and Blackeye Cowpea Mosaic Virus-BICMV (12\%) and $12 \%$ to group specific potyviruses Mab. were detected with ACP ELISA. No positive reactions were found with Bean Golden Mosaic Virus-BGMV. BCMV was found to be more prevails in Guilan province. Mixed infection by viruses was observed in many samples.
\end{abstract}

Keywords: • Cowpea $\bullet$ Virus diseases $\bullet$ Serology $\bullet$ Incidence

\section{Introduction}

Orwh owpea ( Vigna unguiculata L. (Walp) which is the major food legume grown throughout the tropics and sub-tropics is principally used as dry seed (pulse) and also as a vegetable, for fodder and as a cover crop [15]. The seeds of this crop are a good source of protein and calories for humans. For many years viral diseases have caused great yield losses in field-grown cowpeas. Estimated losses due to virus infection which varies depending on the virus-host-vector relationships and prevailing epidemiological factors and have been reported to be between 10 and 100\% [14-11]. The area under cultivation of beans is approximately 4471 hectares in Guilan

*Corresponding Author: Dr. Nooh Shahraeen. Dept. of plant virology, Iranian Institute of plant protection, Tehran, P.O.Box1939-1454, Iran

Tel: 0912122403698 Fax: 0982122403691

E-mail: shahraeen@yahoo.com province [1]. Several viruses are known to infect cowpea world-wide, some of which can cause serious economic losses [4]. Six viruses reported to be seed-borne in cowpea, namely Cowpea Aphid Borne Mosaic Virus (CABMV- genus Potyvirus), Cowpea Mottle Virus(CpMoV,genus Carmovirus), Cowpea Severe Mosaic Virus (CpSMV, genus Comovirus), Southern Bean Mosaic Virus (SBMV, genus Sobemovirus)[10],Blackeye Cowpea Mosaic Virus (BlCMV, genus Potyvirus) and Cucumber Mosaic Virus (CMV, genus Cucumovirus) [3]. There is no quantitative information available on economical importance of the viral diseases affecting cowpea crops, but infection level can reach up to $100 \%$. The aim of this study was to determine which viruses affect cowpea crop in Guilan province and to evaluate their incidence and relative importance with respect to the economical damage they cause. A total of 26 cowpea fields were surveyed (8 location) (table 1 ). Intotal 119 samples with virus like symptoms were collected during the summer 2006 from Guilan 


\section{N. Shahraeen. et.al}

province. Samples included leaves with symptoms from 3 locations of Astara, 3 locations of Sumesara, 3 locations of Shaft, 8 locations of Rasht, 1 location of Lahijan, 6 locations of Astaneh, 1 location of langeroud and 3 locations of Roudesar at Guilan province. The samples were placed in labeled plastic bags and brought to the laboratory by placing on ice bucket and tested for virus infection.

The double - antibody sandwich enzyme - linked immunosorbent assay (DAS - ELISA) [5] was performed with polyclonal antibody against Bean leaf Roll Virus (BLRV-Luteovirus), Cowpea Mild Mottle Virus (CpMMV- Carlavirus), Cowpea Mottle Virus (CpMoV-Carmovirus), Cowpea Mosaic Virus (CpMV-Comovirus), Southern Bean Mosaic Virus (SBMV-Sobemovirus), Cucumber Mosaic Virus (CMV-Cucumovirus), Cowpea Aphid Borne Mosaic Virus (CABMV-Potyvirus), Bean Yellow Mosaic Virus (BYMV-Potyvirus), Cowpea Chlorotic Mottle Virus (CCMV-
Bromovirus) and Bean Golden Mosaic Virus (BGMV-Begomovirus), Tissue blot immuno assay procedure (TBIA) [2-9] was applied using polyclonal antibodies against Cowpea Severe Mosaic Virus (CpSMV-Comovirus), Bean Common Mosaic Virus (BCMV-Potyvirus), Alfalfa Mosaic Virus (AMV-Alfamovirus), Bean Pod Mottle Virus (BPMV-Comovirus), Clover Yellow Vein Virus (CIYVV-Potyvirus) and Peanut Stunt Virus (PSV-Cucumovirus) and monoclonal antibody against Blackeye Cowpea Mosaic Virus (BlCMV-Potyvirus). The antibodies (Pab. And a Mab.) used in this study where supplied by DSMZ Center Germany and Adgen Co,UK.. For detection of Potyviruses, ELISA test was applied using antigen coated plate (ACP- ELISA) [16]. Briefly, samples were mixed in coating buffer and $0.05 \mathrm{M}$ DIECA, incubated overnight at $4^{\circ} \mathrm{c}$, group specific monoclonal antibodies were added at a dilution of $1: 1000$, incubated for $2-4$ hours at $37^{\circ} \mathrm{c}$ and were followed by the addition of RAM alkaline phosphatase conjugate at a dilution of 1:1000.

Table 1: Incidence and distribution of viruses infecting cowpea in Guilan province

\begin{tabular}{lcccccccccc}
\hline $\begin{array}{l}\text { Regions } \\
\text { Viruses }\end{array}$ & Astara & Sumesara & Shaft & Rasht & Lahigan & Astaneh & Langeroud & $\begin{array}{c}\text { Roudsar } \\
\text { Total }\end{array}$ & $\begin{array}{c}\text { Incidence } \\
\%\end{array}$ \\
\hline BLRV & - & $* 4$ & 2 & 2 & - & 2 & 1 & 1 & 12 & 10 \\
\hline CPMMV & - & - & 1 & 2 & - & - & 2 & - & 5 & 4 \\
\hline CPMV & - & 3 & 3 & 4 & - & 1 & 1 & - & 12 & 10 \\
\hline CPSMV & - & 3 & 3 & 8 & - & 1 & - & 1 & 16 \\
\hline SBMV & - & 1 & - & - & - & 1 & - & - & 2 \\
\hline CPMOV & - & 4 & 3 & - & - & 1 & - & - & 8 & 6 \\
\hline
\end{tabular}

\begin{tabular}{|c|c|c|c|c|c|c|c|c|c|c|}
\hline CMV & 1 & 1 & 1 & 10 & - & 3 & - & - & 16 & 13 \\
\hline AMV & - & 3 & 5 & 5 & - & - & - & 2 & 15 & 12 \\
\hline PSV & - & - & 3 & 3 & - & 1 & - & 1 & 8 & 6 \\
\hline BPMV & - & 2 & 3 & 2 & - & - & - & - & 7 & 5 \\
\hline CCMV & - & 1 & 2 & - & - & - & - & - & 3 & 2 \\
\hline BCMV & - & 9 & 6 & 9 & 1 & 4 & - & 1 & 30 & 25 \\
\hline CABMV & - & 1 & - & - & - & - & - & - & 1 & 0.8 \\
\hline BICMV & - & 1 & 4 & 5 & - & 3 & - & 1 & 14 & 11 \\
\hline BYMV & - & 1 & 1 & 1 & - & 1 & - & - & 4 & 3 \\
\hline CIYVV & - & - & - & 2 & - & - & - & 1 & 3 & 2 \\
\hline Potyvirus Mab. & - & 3 & 5 & 4 & - & 3 & - & - & 15 & 12 \\
\hline Total sampled & 3 & 22 & 18 & 40 & 3 & 18 & 7 & 8 & 119 & \\
\hline
\end{tabular}

* = Number of infected plants in each region

- BLRV: Bean Leaf Roll Virus, CpMMV: Cowpea Mild Mottle Virus, CpMV: Cowpea Mosaic Virus, CpSMV: Cowpea Severe Mosaic Virus, SBMV: Southern Bean Mosaic Virus, CpMoV: Cowpea Mottle Virus, CMV: Cucumber Mosaic Virus, AMV: Alfalfa Mosaic Virus, PSV: Peanut Stunt Virus, BPMV: Bean Pod Mottle Virus, CCMV: Cowpea Chlorotic Mottle Virus. BCMV: Bean Common Mosaic Virus, CABMV: Cowpea Aphid - Borne Mosaic Virus, BICMV: Blackeye Cowpea Mosaic Virus, BYMV: Bean Yellow Mosaic Virus, CYVV: Clover Yellow Vein Virus , - = No infection detected.

- Numbers of samples with mix infection were not indicated in the table.

- $\quad$ BGMV ; Bean Golden Mosaic virus was not detected, therefore not listed in Table. 
Virus-free cowpeas grown in an insect-proof cage were used as negative controls. A reaction was considered positive only if the absorbance was more than three times the mean of the negative control. Absorbance at $405 \mathrm{~nm}$ was measured with MCC-340 multiskan labsystem ELISA microplate reader. The reagents for DAS - ELISA, and ACP ELISA were provided by DSMZ center (Brauncheweig-Germany), while TBIA reagents were a gift from Adgen Co, UK. 119 of symptomatic plants samples taken from cowpea fields were analyzed, using DAS-ELISA, ACPELISA and TBIA, to determine the presence and prevalence of the viruses listed in table -1 , in Guilan province of Iran. Potyviruses were identified by the use of the group specific monoclonal antibody. The positive samples from the infected plants with various viruses are shown in Table1. As it is shown the prominent virus infecting the plants was BCMV with the incidence of $25 \%$ and very small number of plants infected with CABMV $(0.8 \%)$ and SBMV (1\%) were detected. However, BGMV was not detected in any of the tested samples. Less viral incidences, CMV in Astara and BCMV in Lahigan regions were recorded. The number of multiple infections (double, triple, and more than triple) was approximately $36.9 \%(44 / 119)$ of the samples found virus infected. $34.9 \%(15 / 44)$ of the infected samples being infected with two viruses, $25 \%$ $(11 / 44)$ with three, $40.9 \%(18 / 44)$ with more than three viruses. In cowpea, the most common double infection was BCMV/CpSMV and CpMV/ CpSMV. The most common triple infection was $\mathrm{BCMV} / \mathrm{CpMoV} / \mathrm{CMV}$.

Cowpea viruses are increasingly important in all cowpea growing areas of Iran. The present study of 119 selected cowpea samples with viral disease like symptoms indicated the incidence of 16 viruses in Guilan province. Occurrence of CABMV, infection of cowpea from Guilan province has been reported previously [7]. Infection by BCMV and CMV in Zanjan and SBMV and BPMV in bean from East Azarbaejan province has been studied by some investigators $[13,12]$, but the incidence of other viral infection listed in table1 has not been investigated. Multiple - virus infections are common among samples from field - grown cowpeas world-wide, and are known to modify and complicate symptomatology. This multiple infection will cause mixed symptoms in the plants which makes diagnosis of the diseases difficult [6-8]. The occurrence of mixtures of viruses confirms the complexity of the problem of a disease resistance breeding program for cowpea production. Identification of host plant and weed species should help in controlling and management of these viruses. Results from this study further demonstrate that field diagnosis of these diseases which are based only on symptoms observation may not be reliable since infection may be caused by multiple viral infection involving up to 5 viruses [6-8]. Continuous periodic surveys are required to evaluate the dynamics of occurrence of cowpea viruses and also to assess other epidemiological factors responsible for their spread. It should be noted that this is the first study reporting multiple viral infection of cowpea in Iran.

\section{References}

1 Anonymous; 2000; Ministry of J-E-Agriculture production year book. Directorate of statistics and information, I.R of Iran pp.36-39.

2 Banttari, E. E. and P. H. Goodwin; 1985; Detection of potato viruses, $\mathrm{X}, \mathrm{S}$ and $\mathrm{Y}$ by enzyme linked immunosorbent assay on nitrocellulose membranes (Dot ELISA). Plant Dis. 69: 202-205.

3 Bashir, M. and R. O. Hampton; 1996; Detection and identification of seed-borne viruses from cowpea (Vigna unguiculata (L.) Walp.) germplasm. Plant Pathology 45: 54-58.

4 Bos, L., R. O. Hampton and K. M. Makkouk; 1988; Viruses and viral diseases of pea, Lentil, Faba bean and Chickpea. - In: Summerfield R. J. (ed.): World crops: cool season food legumes pp: 591-615. Kluwer Academic Publishers, Dordrecht, The Netherlands 1988.

5 Clark, M. F. and A. N. Adams; 1977; Characteristics of the microplate method of enzyme-linked immunosorbent assay for the detection of plant viruses. J. Gen. Virol. 34: 475-483.

6 Harrison, A. N. and R. T. Gudauskas; 1968; Effects of some viruses on growth and seed production of two cowpea cultivars. Plant Dis. Rept. 52: 509-511.

7 Kaiser, W. J., D. Danesh, M. Okhovat and G. Mossahebi; 1972; Virus diseases of pulses crop in Iran. Tehran university publication, Karaj, Iran pp: 10-14.

8 Kuhn, C. W., Brantley, B. B., and G., Jr. Sowell; 1966; Southern pea viruses: identification, symptomatology and sources of resistance. Ga. Agric. Expt. Sta. Bull. 157.

9 Lin, N. S., Hsu, Y. H., Hsu, H. T; 1990; Immunological detection of plant viruses and a mycoplasmalike organism by direct tissue blotting on nitrocellulose membranes. Phytopathology 80, 824.

10 Nadiaye, M., M. Bashir, K. E. Keller and R. O. Hampton; 1993; Cowpea viruses in Senegal, West Africa: Identification, distribution, seed transmission, and source of genetic resistance. Plant Dis. 77: 9991003. 


\section{N. Shahraeen. et.al}

11 Raheja, A. K. and O. I. Leleji; 1974; An aphid-borne mosaic disease of irrigated cowpeas in Northern Nigeria. Plant Disease Reporter 58: 1080-1084.

12 Shahraeen, N. 1993; High incidence of virus diseases in Phaseolus bean in Zanjan province. Proceeding of the $11^{\text {th }}$ plant protection congress of Iran. August 28- Sept.2, Rasht, Iran: 142.

13 Shahraeen, N., and T. Ghotbi; 2005; A survey of viruses affecting French bean (Phaseolus vulgaris) in Iran includes a first report of Southern bean mosaic virus and Bean pod mottle virus. Plant Dis. 89: 1012.

14 hoyinka, S. A. 1974; Status of virus diseases of cowpea in Nigeria. In Proceeding of the First IITA Grain Legume Improvement Workshop, ( Ibadan, Nigeria: International Institute of Tropical Agriculture); pp: 270273.

15 Steele, W. M. and K. L. Mehra; 1980; Structure, evolution, and adaptation to farming system and environments in Vigna. Advances in Legume Science, R. J. Summerfield and A. H. Bunting (Edn.), HMSO, London pp: 393-404.

16 Torrance, L. and R. A. C. Jones; 1981; Recent developments in serological methods suited for use in routine testing for plant viruses. Plant Pathology 30: 124. 